\title{
THE IMPACT OF REMITTANCES ON THE ECONOMIC GROWTH OF PAKISTAN AND INDIA
}

\author{
Prof. Dr. Ghazala Yasmeen* \& Samreen Kamal $\dagger$
}

\begin{abstract}
The international remittances sent back to the home country by migrant workers have a profound impact on the developing countries of Asia, Africa, Latin America, and the Middle East. Official international remittances sent home by migrant workers represent the second most significant source of external funding in the developing countries. Remittances by the international migrants to their countries of origin constitute the largest source of external finance for developing countries after foreign direct investment (FDI) (Adams $\mathrm{Jr}$, 2004). Hence, worker remittances have increased the investment opportunities in the migrant home country. (McCormick \& Wahba, 2000), that in turn have promoted growth in less financially developed countries by providing an alternative way to finance investment (Giuliano \& Ruiz-Arranz, 2009). This research is carried out to determine the impact of remittances on the economic growth of Pakistan and India since economic growth of these countries impact economic stability as well as political stability in the region.
\end{abstract}

Keywords: GDP, Remittances, Growth Rate, FDI, ODI, Migrant, Pakistan, India

\section{Introduction}

Remittances accelerate the economic growth, and promote saving and investment opportunities in the domestic country. (Ahmed et al, 2011).

\footnotetext{
Vice Chancellor, Women University Mardan, Pakistan.

$\dagger$ Qurtaba University Peshawar, Pakistan.
} 
Worker remittances establish an increasingly important mechanism for the transfer of resources from developed to developing countries. They also contribute as the second-largest source behind foreign direct investment of the external funding for developing countries. However, the literature on worker remittances has so far focused mainly on the impact of remittances on income distribution within countries, on the determinants of remittances at a micro-level, or on the effects of migration and remittances for specific countries or regions (Buch \& Kuckulenz, 2004). With the help of remittances, it is easy to get a big chunk of financial flow in a country's economic system. The remittances have effects on income, employment and economic output That help the country to spend more on improving the living conditions, real estate and the acquisition of updated technology (Kalim \& Shahbaz, 2009). Remittance has improved the macroeconomic factors of the country (Vargas-Silva \& Huang, 2006). Private, unrequired transfers are estimated to be bigger and more stable than ODA (Outward Direct Investment) and FDI (Foreign Direct Investment) flows into Ghana since 1990. This is consistent with findings in the literature that in the developing world, remittances now surpass ODA (Outward Direct Investment). The international migration and remittances reduce poverty in developing countries. Adams \& Page analyzed Panel data set including information on international migration, remittances, inequality, and poverty for 71 "low-income and middle-income" developing countries from 1980 onward. They derived that both international migration and remittances have a strong, statistically significant impact on reducing poverty in the developing world (2005). Remittances have a strong and statistically significant impact on poverty reduction; thus, suggesting that there are substantial benefits related with international migration for poor people in developing countries like Pakistan and India. So the importance of remittance inflows cannot be ignored in terms of growth enhancement and poverty reduction as they consequently improve the social and economic conditions of the recipient country (Qayyum et al., 2010). The effect of workers' remittances on economic growth of five South Asian countries, namely Pakistan, India, Bangladesh, Sri Lanka \& Nepal by employing long time series data from 1975 to 2009 . The co-integration results confirmed that there exists a significant, positive and long-run relationship between remittances and the economic growth in India, Bangladesh, Sri Lanka and Nepal; whereas, a significant negative relationship exist between remittances and economic growth in Pakistan and India. Interconnection analysis confirmed bidirectional causality between remittances and economic growth in Nepal and Sri Lanka. Further unidirectional causality exists, runs from 
remittances to economic growth in Pakistan, India and Bangladesh. Sensitivity analysis confirmed that the results are robust. It proposed that policy makers should make policies to reduce the transaction cost to welcome remittances in south Asian countries. In addition to this, countries especially Pakistan should more increased exports rather than workers' remittances as foreign exchange earnings for sustainable and long run growth in the country (Jawaid and Raza, 2012). The remittances can be used as an effective tool for reducing poverty. Different indicators of poverty: a poverty headcount index (measuring the level of poverty), a poverty gap index (measuring the depth of poverty), and a squared poverty gap index (measuring the severity of poverty) constructed by using data from 71 developing countries, that remittances reduce the level, depth, and severity of poverty (Adams and Page, 2005).

\section{Objectives of the Study}

- To investigate empirically the impact of foreign remittances on the economic growth of India and Pakistan.

- To analyze empirically the long run relationship between remittances and the economic growth of India and Pakistan.

\section{Hypotheses}

- $\mathrm{H}_{01}$ : Remittances have insignificant effects on economic growth of India and Pakistan.

- $\mathrm{H}_{11}$ : Remittances do not have significant effects on economic growth of India and Pakistan.

- $\mathrm{H}_{02}$ : There is a positive relationship between remittances and economic growth in the two countries.

- $\mathrm{H}_{12}$ : There is a negative relationship between remittances and economic growth in the two countries.

\section{Research Methodology}

\section{Sample}

Two countries, i.e. India and Pakistan were treated as sample of the study, and ten years' data was collected from 2003 to 2013 for both the countries. 


\section{Variables}

\section{Dependent}

It was hard to examine the all aspects of economic growth. So for the convenience of the study, we selected GDP as a proxy for economic growth in India and Pakistan. In this study, the effects were examined on the economic growths of the respective countries. So the economic growth was treated as a dependent variable of the study.

\section{Independent}

In this study, we analyzed the effects of remittances on GDP. So the remittances were treated as an Independent variable of the study.

\section{Statistical Model}

\section{Regression}

The main objective of the study was to find out the effects of remittances on economic growth of India and Pakistan. The cause and effect model was needed to fulfill the objectives of the study. The linear regression was selected to know the effects of independent variables on dependent variable. The coefficient of determination $\left(\mathrm{R}^{2}\right)$ was calculated in the regression test. These helped to determine the effects of remittances on economic growth of the respective countries. F-statistics was calculated to know the model fitness of the regression model. The purpose of the Fstatistics was to check that weather the model which was adopted is significant or not.

$$
\mathrm{GDP}=\beta_{\mathrm{o}}+\beta_{1} \mathrm{REM}+\varepsilon \ldots \ldots \ldots \ldots \mathrm{i}
$$

Where,

GDP $=$ Gross Domestic Product

REM $=$ Remittances

$\beta_{\mathrm{o}}=$ Intercept

$\beta_{1}=$ Slope in the data

$\varepsilon=$ Error term 


\section{GDP and Remittances of India and Pakistan}

GDP: The gross domestic product (GDP) is one of the primary indicators used to gauge the health of a country's economy. It represents the total dollar value of all goods and services produced over a specific time period .GDP at purchaser's prices is the sum of gross value added by all resident producers in the economy plus any product taxes and minus any subsidies not included in the value of the products. It is calculated without making deductions for depreciation of fabricated assets or for depletion and degradation of natural resources. Data are in current U.S. dollars. Dollar figures for GDP are converted from domestic currencies using single year official exchange rates.

Table 1: GDP of India in USD Billion

\begin{tabular}{|c|c|}
\hline Year & GDP in USD Billion \\
\hline 2003 & 618 \\
\hline 2004 & 722 \\
\hline 2005 & 834 \\
\hline 2006 & 949 \\
\hline 2007 & 1239 \\
\hline 2008 & 1224 \\
\hline 2009 & 1365 \\
\hline 2010 & 1711 \\
\hline 2011 & 1880 \\
\hline 2012 & 1859 \\
\hline 2013 & 1877 \\
\hline
\end{tabular}

Sources include: World Bank. Retrieved on 2015-09-12 
Fig.1a GDP of India in USD Billion

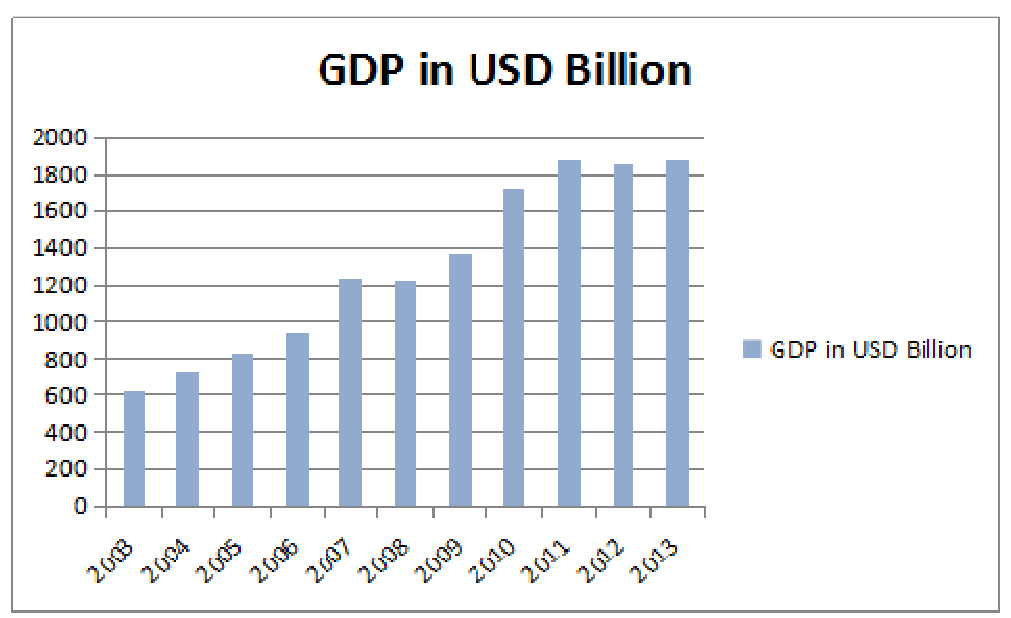

Fig.1.b

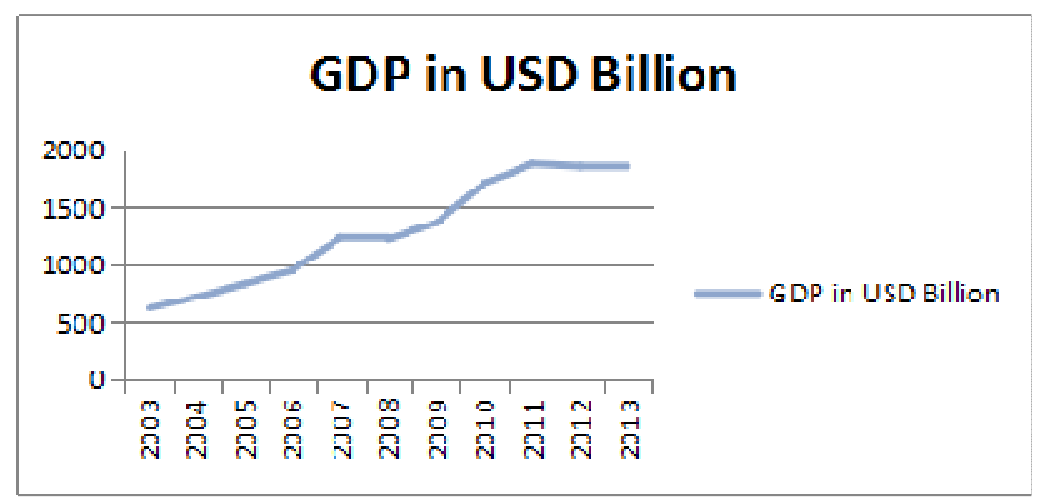

The table.1, fig.1a and fig.1b are representing the variation in the gross domestic product of India. In 2003 the GDP of India was 618 billion dollars then it rose to 722 in 2004 . After that in 2005 the GDP slightly increased from 722 to 834 billion dollars. Whereas in 2006 the GDP increased to 949 billion dollars then in 2007 significant upturn of 1239 billion dollars occurred. In 2008 a minor decrease made the GDP to 1224 billion dollars. While in 2009 it increased slightly and rose to 1365 billion dollars and in 2010 it increased sharply to 1711 . In 2011, it slightly increased and raised to 1880 billion dollars while in 2012 GDP was 1859 billion dollars that showed a comparatively low decrease. In 2013the GDP was 1877 billion dollars. 
Table 2: GDP of Pakistan

\begin{tabular}{|c|c|}
\hline Years & GDP USD Billion \\
\hline 2003 & 83 \\
\hline 2004 & 98 \\
\hline 2005 & 110 \\
\hline 2006 & 137 \\
\hline 2007 & 152 \\
\hline 2008 & 170 \\
\hline 2009 & 168 \\
\hline 2010 & 177 \\
\hline 2011 & 214 \\
\hline 2012 & 225 \\
\hline 2013 & 237 \\
\hline
\end{tabular}

Sources include: World Bank. Retrieved on 2015-09-15.

Fig.2.a.GDP of Pakistan

Pakistan - GDP

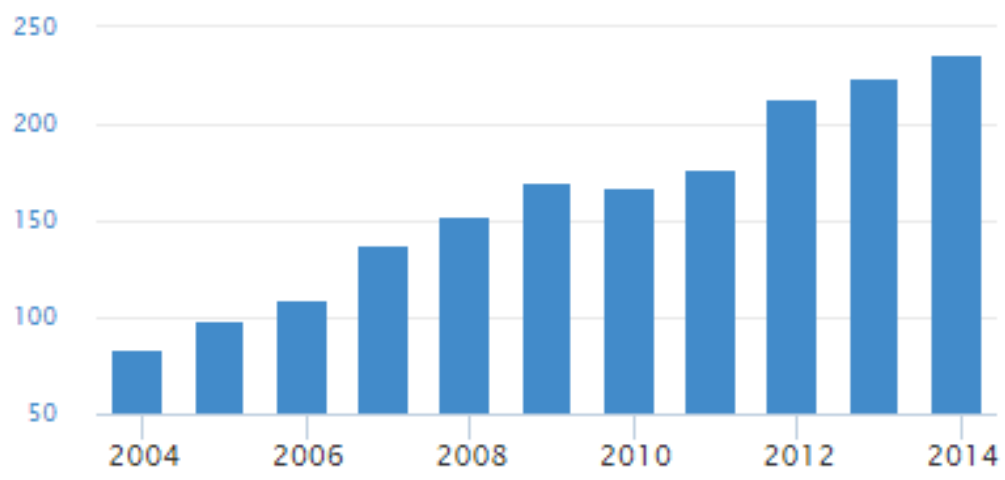


Fig.2.b.GDP of Pakistan

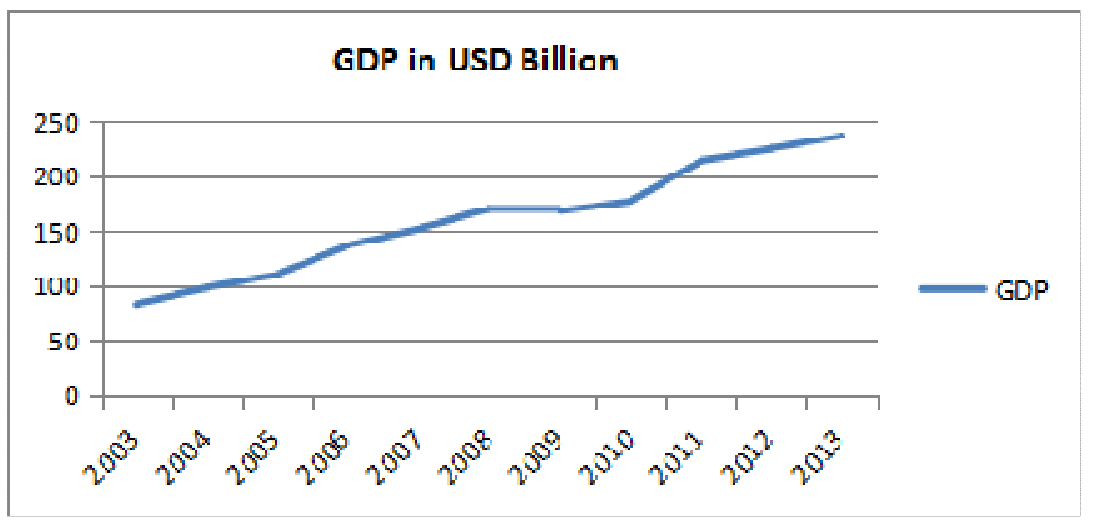

The table.2, fig.2a and fig. $2 \mathrm{~b}$ are representing the variation in the gross domestic product of Pakistan. In 2003, the GDP of Pakistan was 83 Billion Dollars, and then it rose to 98 in 2004. After that in 2005, the GDP abruptly increased from 98 to 110 Billion Dollars; whereas, in 2006 the GDP increased to 137 Billion Dollars then in 2007 significant upturn of 157 Billion Dollars occurred. In 2008 slightly increased and raised to 170 Billion Dollars. In 2009, a minor decrease made the GDP to 168 Billion Dollars, while in 2010 it increased slightly and rose to 177 Billion Dollars, and then in 2011 it increased sharply to 214 Billion Dollars. In 2012, it slightly increased and rose to 225 Billion Dollars; while in 2013, the GDP was 237 Billion Dollars that showed a comparatively great increase.

\section{Remittances}

Remittances: Remittances refer to the transfer of money by a foreign worker to an individual in his or her home country. Money sent home by migrants competes with international aid as one of the largest financial inflows to developing countries. Workers' remittances are a significant part of international capital flows especially in the case of labor-exporting countries. 
Table 3: Remittances of India in USD Billion

\begin{tabular}{|c|c|}
\hline Year & $\begin{array}{c}\text { Remittances of India } \\
\text { in USD Billion }\end{array}$ \\
\hline 2003 & 16.39 \\
\hline 2004 & 21.61 \\
\hline 2005 & 20.25 \\
\hline 2006 & 24.55 \\
\hline 2007 & 29.1 \\
\hline 2008 & 37.2 \\
\hline 2009 & 51.6 \\
\hline 2010 & 55.06 \\
\hline 2011 & 66.1 \\
\hline 2012 & 67.6 \\
\hline 2013 & 70.39 \\
\hline
\end{tabular}

Source:

1. Chishti, Muzaffar (February 2007). "The Rise in Remittances to India: A Closer Look". Migration Information Source. Archived from the original on 2010-12-04. Retrieved on 2015-09-12.

2. " Remittances to India, 1970 to 2008". Migration Information Source. Archived from the original on 2010-12-04d. Retrieved on 2015-09-12.

Fig 3a. Remittances of India in USD Billion

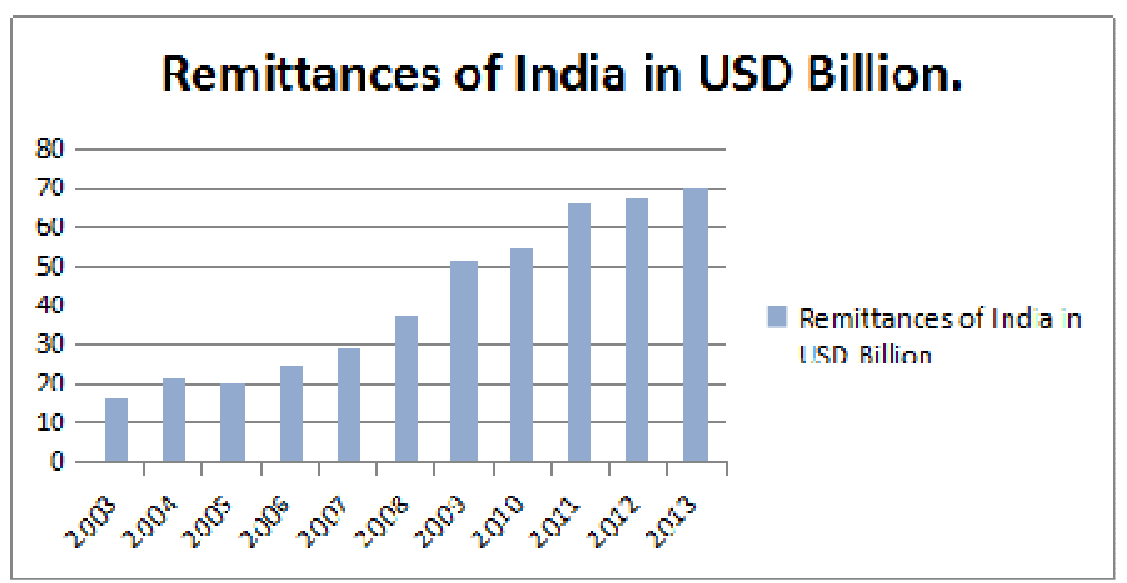


Fig.3b

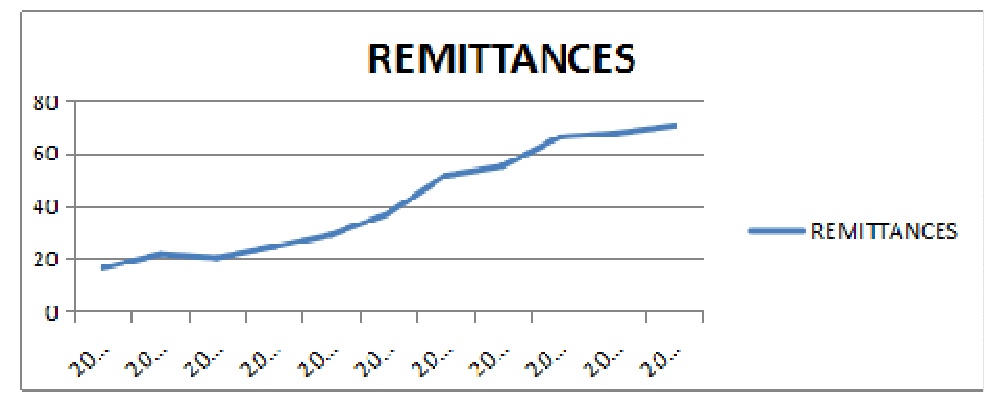

The table.3, fig.3a and fig.3b show the remittances of India. In 2003, remittances were 16.39 and in 2004 the remittances slightly increased to 21.61 Billion Dollars; while in 2005, the remittances decrease to some extent i.e. 20.25. In 2006, the remittances sharply increased to 24.55 Billion Dollars while again in 2007 increased to 29.10. In 2008, tremendous increase has been observed and remittances rose to 37.2 Billion Dollars. Then a significant change in remittances in the year 2009 occurred that further increase the remittances to 51.6 Billion Dollars. In 2010 a continuing upward change raised the remittances to 55.06 Billion Dollars. In 2011, the remittances were 66.1 Billion Dollars then a gradual increase happened and remittances were 67.6 Billion Dollars in 2012. The decade 200 -2013 ended with 70.39 Billion Dollars in 2013.

Table 4. Remittances of Pakistan

\begin{tabular}{|c|c|}
\hline Year & $\begin{array}{c}\text { Remittances in Pakistan USD } \\
\text { Billion }\end{array}$ \\
\hline 2003 & 4.23 \\
\hline 2004 & 3.8 \\
\hline 2005 & 4.6 \\
\hline 2006 & 5.493 \\
\hline 2007 & 6.00 \\
\hline 2008 & 6.5 \\
\hline 2009 & 8.72 \\
\hline 2010 & 9.69 \\
\hline 2011 & 12.26 \\
\hline 2012 & 14.01 \\
\hline 2013 & 14.63 \\
\hline
\end{tabular}


Fig.4.a. Remittances of Pakistan in USD Billion

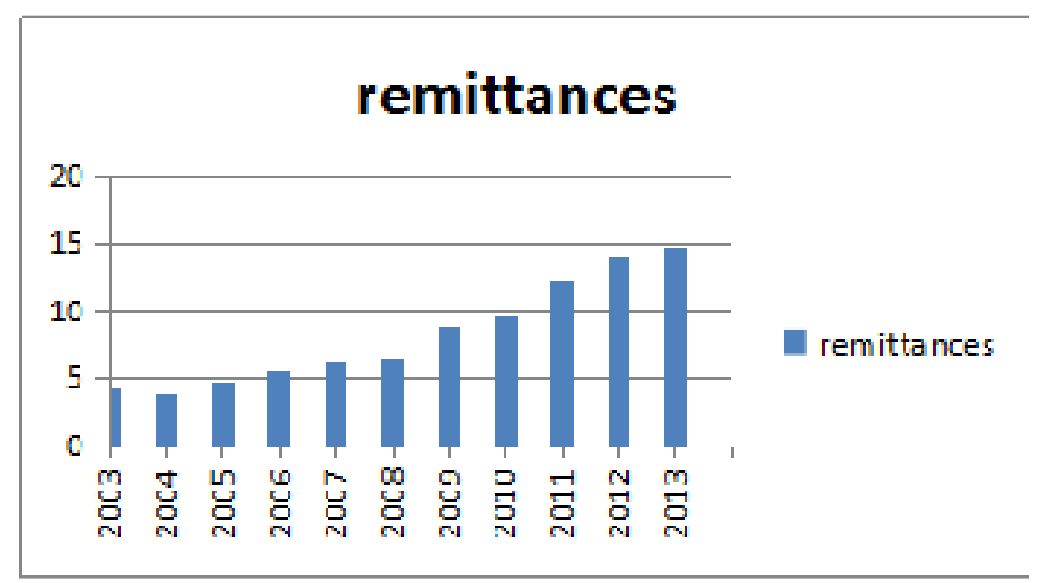

Fig.4b.Remittances of Pakistan in USD Billion

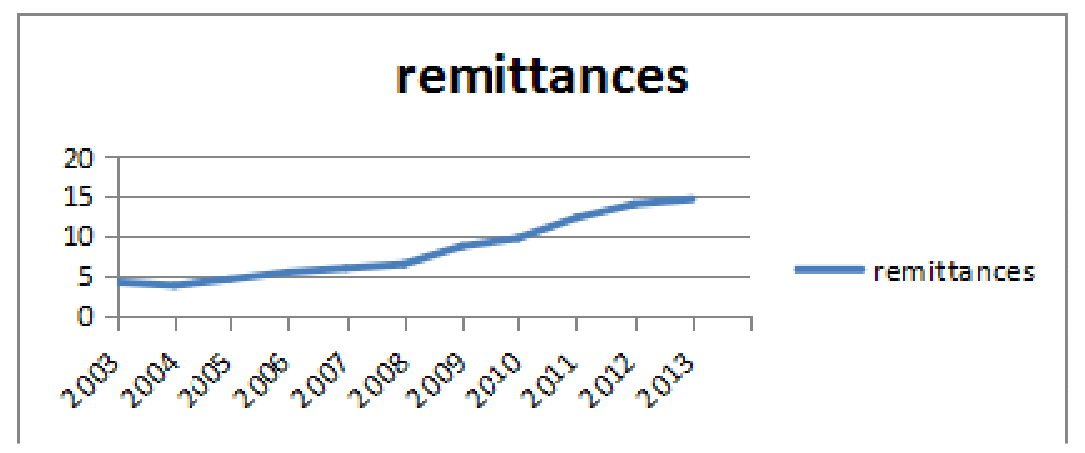

The table.4, fig.4a and fig.4b show the remittances of Pakistan. In 2003, the remittances were 4.23 and in 2004 the remittances slightly decreased to 3.8 Billion Dollars; while in 2005, the remittances increase to some extent i.e. 4.6. In 2006, the remittances sharply increased to 5.493 Billion Dollars while in 2007 increased to 6.00. Then a significant change in remittances in the year 2008 occurred that further increase the remittances to 6.5 Billion Dollars. In 2009, a tremendous increase has been observed and remittances rose to 8.72 Billion Dollars. In 2010, a continuing upward change raised the remittances to 9.69 Billion Dollars. In 2011 the remittances were 12.26 Billion Dollars then a gradual increase happened and remittances were14.01 
Billion Dollars in 2012. The decade 200 -2013 ended with 14.63 Billion Dollars in 2013.

\section{Results and Discussion}

\subsubsection{Relationship between remittances and GDP}

$$
\mathrm{GDP}=\beta_{\mathrm{o}} \mathrm{i}+\beta_{1} \mathrm{i} \mathrm{REM}+\varepsilon \ldots \ldots \ldots
$$

As explained in the methodology that the econometric model shows the effect of remittances on economic growth in India and Pakistan

Where,

GDP $=$ Economic Growth of the country

REM $=$ Remittances of the country

$\beta_{\mathrm{o}}=$ Intercept

$\beta_{1}=$ Slope in the data

$\varepsilon=$ error term

\section{Results for India}

Model Summary

\begin{tabular}{|c|c|c|c|c|}
\hline Model & R & R Square & $\begin{array}{c}\text { Adjusted R } \\
\text { Square }\end{array}$ & $\begin{array}{c}\text { Std. Error of the } \\
\text { Estimate }\end{array}$ \\
\hline 1 & $.973^{\mathrm{a}}$ & .947 & .941 & 117.00755 \\
\hline
\end{tabular}

a. Predictors: (Constant), Remittances

\begin{tabular}{|c|c|c|c|c|c|c|}
\hline \multicolumn{7}{|c|}{ ANOVA $^{b}$} \\
\hline \multicolumn{2}{|r|}{ Model } & $\begin{array}{c}\text { Sum of } \\
\text { Squares }\end{array}$ & df & $\begin{array}{l}\text { Mean } \\
\text { Square }\end{array}$ & $\mathbf{F}$ & Sig. \\
\hline \multirow[t]{3}{*}{1} & Regression & 2180757.103 & 1 & 2180757.103 & 159.287 & $.000^{\mathrm{a}}$ \\
\hline & Residual & 123216.897 & 9 & 13690.766 & & \\
\hline & Total & 2303974.000 & 10 & & & \\
\hline
\end{tabular}

a. Predictors: (Constant), Remittances

b. Dependent Variable: GDP

\section{Co-efficient}

\begin{tabular}{|c|c|c|c|c|c|c|}
\hline \multirow{2}{*}{\multicolumn{2}{|c|}{ Model }} & \multicolumn{2}{|c|}{$\begin{array}{l}\text { Unstandardized } \\
\text { Coefficients }\end{array}$} & \multirow{2}{*}{\begin{tabular}{|c} 
Standardized \\
Coefficients
\end{tabular}} & \multirow[b]{2}{*}{$\mathbf{T}$} & \multirow[b]{2}{*}{ Sig. } \\
\hline & & B & Std. Error & & & \\
\hline & (Constant) & 361.243 & 82.181 & & 4.396 & .002 \\
\hline & VAR00001 & 22.408 & 1.775 & .973 & 12.621 & .000 \\
\hline
\end{tabular}

a. Dependent Variable: GDP 


\section{Results for Pakistan}

Model Summary

\begin{tabular}{|c|c|c|c|c|}
\hline Model & R & R Square & $\begin{array}{c}\text { Adjusted R } \\
\text { Square }\end{array}$ & $\begin{array}{c}\text { Std. Error of the } \\
\text { Estimate }\end{array}$ \\
\hline Pak & $.954^{\mathrm{a}}$ & .910 & .901 & 16.19629 \\
\hline
\end{tabular}

a. Predictors: (Constant), remittances

ANOVA ${ }^{\mathbf{b}}$
\begin{tabular}{|c|l|c|c|c|c|c|}
\hline \multicolumn{2}{|c|}{ Model } & $\begin{array}{c}\text { Sum of } \\
\text { Squares }\end{array}$ & df & $\begin{array}{c}\text { Mean } \\
\text { Square }\end{array}$ & F & Sig. \\
\hline \multirow{2}{*}{1} & Regression & 24017.123 & 1 & 24017.123 & 91.557 & $.000^{\text {a }}$ \\
\cline { 2 - 8 } & Residual & 2360.877 & 9 & 262.320 & & \\
\cline { 2 - 8 } & Total & 26378.000 & 10 & & & \\
\hline
\end{tabular}

a. Predictors: (Constant), Remittances

Coefficients $^{\mathrm{a}}$

\begin{tabular}{|c|c|c|c|c|c|c|}
\hline & \multirow[b]{2}{*}{ Model } & \multicolumn{2}{|c|}{$\begin{array}{l}\text { Unstandardized } \\
\text { Coefficients }\end{array}$} & \multirow{2}{*}{\begin{tabular}{|c|}
$\begin{array}{c}\text { Standardized } \\
\text { Coefficients }\end{array}$ \\
Beta \\
\end{tabular}} & \multirow[b]{2}{*}{$\mathbf{t}$} & \multirow[b]{2}{*}{ Sig. } \\
\hline & & B & Std. Error & & & \\
\hline \multirow[t]{2}{*}{1} & (Constant) & 59.947 & 11.635 & & 5.152 & .001 \\
\hline & Remittances & 12.360 & 1.292 & .954 & 9.569 & .000 \\
\hline
\end{tabular}

a. Dependent Variable: GDP

\section{Explanation of the Model}

The above results interpret the following points:

For India,

$$
\mathrm{GDP}=361.24+22.408 \mathrm{Rem}
$$

In the model 361.24 is intercept, it is the value when remittance is equal to zero. This means that if remittances of India are zero then GDP of India will be 361.24. The slope is 22.408, which means that when there is increase of $1 \%$ in remittances it will lead to increase of $22.4 \%$ in GDP.

Whereas for Pakistan,

$$
\mathrm{GDP}=59.95+12.36 \mathrm{Rem}
$$

In the model 59.95 is intercept, it is the value when remittances is equal to zero this mean that if remittances of Pakistan are zero then GDP of Pakistan will be 59.95. The slope is 12.36 , which means that when there is increase of $1 \%$ in remittances, it will lead to increase of $12.4 \%$ in GDP. 
It is to be mentioned here that remittances and GDP are positively corelated; if remittances increase, GDP will also increase, and vice versa.

\section{T-statistics}

The relationship between remittances and GDP is statistically significant, because the value of t-test is greater than 2 .

\section{F-statistic}

F-statistics shows the overall significance of the model. The probability of F-statistics is 0.000 which is less than 5\%, which shows the overall model is significant.

\section{Co-efficient of Determination}

The linear regression model shows that the regression line is good fit, because the value of $\mathrm{R}$-Square is greater than $50 \%$, i.e. $94 \%$ variation in GDP is due to remittances in India, whereas it is $91 \%$ for Pakistan, which is also greater than $50 \%$.

\section{Conclusion}

The research was conducted to determine the Impact of remittances on GDP Growth of India and Pakistan from 2003 to 2013. Simple liner regression model was used. The results show that impact of remittances on GDP is more than $22 \%$ for India and $12 \%$ for Pakistan. India has $94 \%$ of variation in GDP due to remittances, while Pakistan has $91 \%$. Both the hypotheses are accepted.

\section{References}

Adams Jr, R. H. (2004). Remittances and poverty in Guatemala. World Bank Policy Research Working Paper(3418).

Adams, R. H., \& Page, J. (2005). Do International Migration and Remittances Reduce Poverty in Developing Countries? World development, 33(10), 1645-1669.

Ahmed, J., Zaman, K. and Shah, I. A. 2011: An Empirical Analysis of Remittances-Growth

Nexus in Pakistan Using Bound Testing Approach. Journal of Economics and International Finance 3 (3), 176-186. 
Giuliano, P., \& Ruiz-Arranz, M. (2009). Remittances, Financial Development, and Growth. Journal of Development Economics, 90(1), 144-152.

Jawaid,S.T and Raza,S.A.2012. Workers' Remittances and Economic Growth in South Asia.J. MPRA Paper No. 39001, posted 24.

Kalim, R., \& Shahbaz, M. (2009). Remittances and Poverty Nexus: Evidence from Pakistan. International Research Journal of Finance and Economics, 29, 46-59.

McCormick, B., \& Wahba, J. (2000). Overseas Employment and Remittances to a Dual Economy. The Economic Journal, 110(463), 509534.

Qayum, Abdul, Muhammad Javid, and Umaima Arif (2010) Impact of Remittances on Economic Growth and Poverty: Evidence from Pakistan.(MPRA Paper No. 22941).

Vargas-Silva, C., \& Huang, P. (2006). Macroeconomic Determinants of Workers' Remittances: Hostversus Home Country's Economic Conditions. Journal of International Trade \& Economic Development, 15(1), 81-99. 